\title{
High-growth entrepreneurial firms in Africa: a quantile regression approach
}

\author{
Micheline Goedhuys • Leo Sleuwaegen
}

Accepted: 15 March 2009/Published online: 18 April 2009

(C) The Author(s) 2009. This article is published with open access at Springerlink.com

\begin{abstract}
This article analyses the growth performance of a large set of entrepreneurial firms in ten manufacturing sectors of 11 Sub-Saharan African countries. The focus of the article is on identifying those entrepreneurs' attributes and firm characteristics that tend to generate a significant number of highgrowth firms in these countries. To this end, we use a quantile regression, which provides a more complete estimation of the growth distribution of firms conditional on different attributes. The results indicate that firms that engage in product innovation, have their own transport means and are connected to the internet through their own website are especially characterized by higher growth rates and also display a distribution of growth rates skewed to the right, hosting a higher number of high-growth firms. The effect of the last two variables, which relate to distance-bridging modes of infrastructure, points to the self-reinforcing growth effects they generate in creating wider input and output markets. Education raises growth opportunities by affecting the lower quantiles, but it does not appear to influence the upper
\end{abstract}

M. Goedhuys ( $\square)$

UNU-MERIT and Maastricht University,

Maastricht, The Netherlands

e-mail: Goedhuys@merit.unu.edu

L. Sleuwaegen

Vlerick Leuven Gent Management School,

Catholic University of Leuven, Leuven, Belgium

e-mail: leo.sleuwaegen@econ.kuleuven.be quantiles. The estimated conditional growth distributions for the technology-intensive machinery and electronics sectors show more extreme tails and a lower mean in comparison to the traditional industries, indicating the more risky nature of doing business in these industries.

Keywords Africa - Firm growth -

High-growth firms · Quantile regression

JEL Classifications D92 $\cdot$ L26 $\cdot$ O55

\section{Introduction}

A thriving class of entrepreneurial firms is generally recognized as necessary for providing the potential for employment creation and wealth. It is even more important in the least developed countries (LDCs), many of which have gone through a period of conflict, to foster productive and high-growth entrepreneurship that can contribute to peace and transition (UNCTAD 2006; Naudé 2007). The growing share of the non-agricultural labour force also highlights the need for employment creation in the productive sector, beyond the proliferation of marginal/informal trade and service activities that are traditionally associated with entrepreneurship in Africa. Strongly growing firms have the potential to create employment and technological capabilities and to generate physical and human capital formation. 
Several efforts have been made recently to define and identify high-growth firms (HGFs) in the context of the advanced economies (see, for example, Delmar et al. 2003; Eurostat-OECD 2007; Acs et al. 2008). For developing countries also, including Sub-Saharan Africa (SSA), a better understanding of the prevalence and incidence of HGFs is highly relevant. The need to gain better insights into the existence, characteristics and stimulating factors of high-growth firms in this region is pressing, but sharply contrasts with the patchy empirical evidence on this topic.

Almost all studies dealing with firm growth show a wide dispersion of growth rates across firms. Many unidentified and unobservable (firm-specific) factors are held responsible for these wide differences in growth performance of firms. However, since the seminal work of Jovanovic (1982), firm growth has been increasingly modelled as a learning process to explain why small and young firms grow faster, once they discover in confronting the market that they can stand up to competition. The model has been successfully tested in the context of both developed and developing countries. Studies focusing on developing countries have indicated that in addition to the learning process, the growth of firms is influenced by a larger set of other variables, including the specific characteristics of entrepreneurs and a wide range of constraining factors from both the demand and supply conditions in those countries (Sleuwaegen and Goedhuys 2002).

Empirical regression models have been able to explain how the growth of the firm is influenced by these variables. Typical for regression analysis, these studies show how the mean of the (conditional) distribution of firm growth rates changes systematically with these co-variates. The fact that these regression models explain little of the variation in firm growth rates-leaving the large role to the socalled erratic or stochastic component of firm growth-has often been overlooked. Moreover, classical regression studies assume that deviations from the mean of the conditional distribution are distributed in the same way, whatever the values of the covariates. As emphasized by Koenker and Hallock (2001), the classical regression approach boils down to a location shift model, assuming that the co-variates affect only the location of the conditional distribution of growth rates, and not the scale or shape of it (Koenker 2005).
In the analysis reported here, we make less restrictive assumptions in analysing the complete conditional distribution of firm growth rates. Using quantile regressions, we investigate to what extent certain co-variates may affect the conditional distribution of firm growth rates more fundamentally, by changing its location, scale and shape (Koenker and Bassett 1978; Buchinsky 1998; Koenker 2005). We are interested not only in the factors that systematically increase the 'mean' growth rates of firms, but also in the factors that tend to stretch the right tail of the conditional distribution of growth rates; in other words, factors that tend to generate a significant number of high-growth firms.

Indeed, if the aim is to stimulate the number of HGFs in the economy, an examination of the complete firm growth distribution contingent on the different firm characteristics and the demand and supply conditions appears more appropriate. If certain features generate a more stretched distribution, thereby widening the upper tail, these factors can be as crucial in explaining the prevalence of highgrowth firms in the economy as the factors that systematically affect the mean firm growth rate. The results of our analysis indicate that after controlling for a set of growth enhancing factors, firms that engage in product innovation, have their own transport means, and are connected to the internet through their own website are characterized not only by higher growth rates, but also display a distribution of growth rates skewed to the right, hosting a higher number of HGFs. The influence of the last two variables emphasizes the self-reinforcing growth effects generated by distance-bridging modes of infrastructure, which create wider input and output markets.

These results follow from an analysis on the prevalence and determinants of high-growth entrepreneurship in 11 SSA countries, eight of which are listed in the United Nations' classification as LDCsAngola, Burundi, Rwanda, Congo D. R., the Gambia, Guinea Bissau, Guinea, Tanzania-and three other developing countries-Swaziland, Botswana and Namibia. These countries have received little attention in the economic literature for a variety of reasons, including the small size of their economy, existing language barriers and scarcity of data and information. Some empirical studies, however, have been carried out to examine the barriers to growth of 
firms in Africa, investigating why firms fail to move up from micro- or small- to medium- or large-scale operations. However, these studies did not give specific attention to the group of high-growth firms, which in particular have the potential to create quality employment as technological capabilities develop. The availability of a wider set of harmonized firmlevel data, collected by the World Bank Investment Climate Survey (ICS; 2006) allows us to better analyse the factors that foster high-growth African firms.

In Sect. 2, we present the findings of a rich empirical and theoretical literature on firm growth and identify the factors that have been found to influence firm growth, with a special emphasis on studies from Africa. Section 3 presents some basic evidence on the existence of HGFs in various African countries. The World Bank dataset is used for the empirical analysis, which is first described in this section and then, following the definition of HGFs, is elaborated upon. Section 4 subsequently estimates a growth model to identify the factors that affect growth at various levels of the growth distribution. The first part of this section explains the two estimation techniques used: least squares assuming homoscedastic normal conditional growth distributions, and quantile regression, allowing for more general conditional growth distributions, while the second part explains the construction of the variables, and the third part presents the estimation results. Section 5 interprets the findings and ends with a discussion of some of the limitations of this study.

\section{Determinants of high-growth firms: insights from the literature}

There are many unidentified and unobservable firmspecific factors that are responsible for the growth performance of firms. This is strongly recognized in the literature on firm growth that builds on Gibrat's (1931) 'law of proportionate effect', which in its strongest form implies that growth is completely random. A growing number of studies reject Gibrat's law of complete randomness of firm growth, finding that there are systematic observable factors, such as size, age, innovation, entrepreneur characteristics and resources, that do affect the growth of firms. A large set of classical regression studies provide evidence that the mean of the distribution of growth of firms changes systematically with the value of these observable factors. However, these studies pay no attention to the possible interactions of these factors with the unobserved firm-specific factors that characterize the dispersion of growth performance of firms around the mean. An exception is Coad and Rao (2008) who, similarly to our work, use quantile regression to analyse the impact of innovativeness on the growth of U.S. firms.

Indeed, if the aim of policymakers is to stimulate the number of high-growth firms in the economy, an examination of the firm growth distribution that is contingent on the different firm characteristics and demand and supply conditions appears to be more appropriate. For increasing the number of HGFs in the economy, altering the factors that have a stronger impact in the upper tail of the conditional distribution will likely be as effective as affecting the factors that shift the distribution upward.

In what follows we survey the literature in search of the factors that are likely to affect growth distribution in a variety of ways, with a special emphasis on findings from Africa. However, the literature to date has focused on factors that affect the mean of growth distributions. Our aim is to investigate whether these effects are the results of a pure location shift of the mean growth rate or whether they result from a more fundamental impact these factors have on the complete distribution of firm growth rates. We are particularly interested in identifying the factors that have a strong effect in the upper tail of the growth distribution, where high-growth firms are situated.

\subsection{Firm size and age}

A large body of empirical studies ${ }^{1}$ find a significant negative relationship between firm growth and size (Mansfield 1962; Kumar 1985; Evans 1987; Dunne and Hughes 1994; Goddard et al. 2002; Yasuda 2005; Calvo 2006) and between the variability in growth and firm size. The higher and erratic growth rates of smaller firms are related to the small size at which

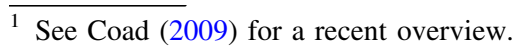


firms enter vis-à-vis the minimum efficient scale (MES), dictated by the technological conditions of the industry. Confronted with this scale cost-disadvantage, surviving small firms will grow rapidly to reach the MES, also allowing that above the MES, growth may be random. ${ }^{2}$

Similarly, a negative relationship between firm growth and firm age is observed (see, for example, Evans 1987; Variyam and Kraybill 1992; Dunne and Hughes 1994; Yasuda 2005; Calvo 2006) and between the variability in growth and firm age. Smaller and younger firms grow faster than larger, older ones, but the volatility in their growth rates is also higher, as are their hazard rates. This observation lends support for the insights provided by Jovanovic's (1982) passive 'Bayesian' learning model of firm growth. Firms enter the industry with different relative (fixed) efficiency levels. Once established in the industry, firms learn about their efficiency, especially in their first years, with the least efficient ones being forced to exit, while more efficient firms expand.

The size-age-growth relationships have also been successfully tested in the context of African firms. Biggs and Srivastava (1996), McPherson (1996), Goedhuys and Sleuwaegen (1999), Sleuwaegen and Goedhuys (2002) and Bigsten and Gebreeyesus (2007) provide empirical evidence that younger and smaller firms have higher growth rates than larger and older companies. However, important non-linearities in the size-growth and age-growth have also been found: Sleuwaegen and Goedhuys (2002) find a positive interaction effect between firm size and age on the growth of Ivorian firms, implying that firms starting at a larger size tend to regress more slowly in terms of growth rate over time than smaller firms. Bigsten and Gebreeyesus (2007) note the age effect to be negative for Ethiopian firms in their early years of activity, yet turning positive for older firms, when firms are likely to benefit increasingly from reputation effects.

\footnotetext{
${ }^{2}$ Surveying the literature, Caves (1998) indeed concludes that growth is independent of size above a certain size threshold. In a selection model by Audretsch (1995), conditional on survival, firms in industries with large-scale economies exhibit higher rates of growth than firms in industries where scale economies are relatively unimportant.
}

\subsection{Innovation and capabilities}

In line with the resource-based view of the firm (Penrose 1959), there is broad theoretical reasoning that firm-specific investments in innovation and Research and Development (R\&D) raise competence and open up growth opportunities (Aghion and Howitt 1992; Geroski 2000; see Coad 2009 for a discussion). However, innovation in the early stage of the product life-cycle also raises uncertainty in the industry, as emphasized in the work of Gort and Klepper (1982). Empirical evidence on the innovation-growth relationship is mixed, primarily due to the time lag in translating new knowledge into new products or production processes to boost firm growth, and the measurement problems that complicate this research. A positive effect of innovation is found for sales growth in developed economies (Geroski and Toker 1996; Roper 1997; Freel 2000). Coad and Rao (2008) discover a positive effect of innovativeness for high-growth firms in the upper tail of the distribution, but not for the average firm's sales growth. For employment growth, the picture is more ambiguous. Product innovations generally have a positive impact on employment (Harrison et al. 2005 for four European countries; Calvo 2006 for Spain; Benavente and Lauterbach 2008 for Chile). However, process innovations may entail a labour-saving component and appear to have a negative (Harrison et al. 2005), positive (Calvo 2006) or have no impact on employment (Benavente and Lauterbach 2008 for Chile).

For developing countries, where a majority of firms are operating substantially below the technological frontier, firms' innovation efforts are primarily oriented towards absorbing, adapting, mastering and eventually improving technologies developed elsewhere. Several authors point to the importance of 'technological capabilities' of firms in developing countries with respect to the knowledge and skillstechnical, managerial and institutional-necessary for firms to utilize equipment and technology efficiently (e.g., Enos 1992; Lall 1992; see also UNCTAD 1996 for an overview). Firms build up these technological capabilities by engaging in a wide variety of activities, such as training of the workforce, investment in new vintage machinery and the use of Internet and computer technology (ICT) and technology licensing from abroad, aimed at introducing products and 
production processes that are new to the firm and reinforcing the firm's competitive position.

There is less empirical evidence on the effect of capabilities on growth for African countries, where the empirical literature has focused more on the human capital and sociological features of the entrepreneur (Bigsten and Söderbom 2006). Human capital variables appear to be systematic variables affecting firm growth, especially in the many small African firms where the entrepreneur has a dominant role in the development of the firm.

\subsection{Entrepreneur characteristics}

A rich literature, summarized by Van Der Sluis et al. (2004) and including evidence from at least 20 African countries, has investigated the impact of schooling and experience on entrepreneurial performance. They provide evidence supporting the idea that more highly educated entrepreneurs show superior entrepreneurial performance. The impact of education on entrepreneurship selection is mixed, since higher education not only raises managerial ability, but also increases outside options for paid wage employment. Similar results are noted for Côte d'Ivoire (Goedhuys and Sleuwaegen 2000), where lower levels of education and vocational training seemed to positively influence the likelihood of being entrepreneurs versus wage workers, but higher education was needed for post-entry firm growth.

A number of studies also investigate the role played by ethnic minority entrepreneurs and, in particular, how they succeed in using their minority community networks of trust to overcome credit and information constraints, thereby reaching superior levels of entrepreneurial success (e.g., Mengistae 1999; Ramachandran and Shah 1999; Fisman 2003; Biggs and Shah 2006). Hewitt and Wield (1997) also mention Asian businesses in the Tanzanian industry as having 'access to sources of technology, which are not so easily available to other Tanzanian industrialists'.

The gender factor has also increasingly received attention in the entrepreneurship literature. Despite a number of exceptions, only a small proportion of entrepreneurs in manufacturing are women, and their businesses experience lower growth (McPherson 1996; Mead and Liedholm 1998; Goedhuys and
Sleuwaegen 2000), pointing to additional barriers for women to engage in formal manufacturing ventures.

\subsection{Resources}

Finally, the growth of firms in Africa is particularly constrained by factors related to the low level of development in input markets (Sleuwaegen and Goedhuys 2002). Tybout (2000) investigates the size distribution of firms in LDCs and concludes that the proliferation of very small firms results from a particular business environment characterized by small market sizes, low levels of human capital, lack of access to inputs, and poor infrastructure, such as roads, ports, communication facilities and provision of energy. Poor transportation networks directly affect the costs of servicing distant markets, and they are particularly limiting in the least developed, more agrarian economies, where consumers are spread throughout the countryside, resulting in small pockets of demand in geographically diffuse markets. In instances where infrastructure services are missing or unreliable, some firms must produce their own power, transport and/or communication services (Tybout 2000). In addition, overregulation and corruption, political instability and uncertain macroeconomic conditions increase the risk level associated with entrepreneurship.

From this situation follows that the provision of a good transportation and communications network and the availability of the necessary equipment at the firm level are key elements for widening the relevant market in which firms can grow. The market-widening process will produce self-reinforcing effects for growth. If low transport and communication costs can be combined with scale economies in production and distribution, unit costs will decline and render goods affordable for more customers. Similarly, if the firm can efficiently reach more customers, network effects in demand may likewise stimulate extra growth. We expect these self-reinforcing effects to be significant for shifting the growth distribution upwards, but also in terms of interaction with the unobservable factors, including firm-specific competence, we expect these factors to stretch the growth distribution to the right.

The next section presents the dataset used and compares the prevalence of HGFs in Africa with that in some European countries. 


\section{The prevalence of high-growth entrepreneurial firms in Sub-Saharan countries}

\subsection{Data source}

To investigate the existence of high-growth firms in Africa and to identify the factors that foster them, we use recently collected firm-level data from the World Bank Investment Climate Survey (2006). ${ }^{3}$ The objective of the ICS is to obtain firm-level data that allow the conditions for investment and enterprise growth in the respective countries to be analysed. The survey was conducted in 2006 in the 11 selected African countries, using a harmonized questionnaire. This allowed pooling of the datasets of the various countries, which generated a sufficiently large number of firms for conducting more advanced econometric analyses. For the purpose of our analysis, the survey contains historical data on employment for 2002 and 2005, which enable us to examine growth over a 3-year period. In addition, the ICS contains interesting information on the background of the entrepreneur, technological characteristics of the firm and institutional constraints to growth.

After pooling the data from the 11 African countries, we imposed additional criteria to construct a sample of firms appropriate to the specific analysis. First, we selected only firms with at least five workers (leaving out informal firms with little growth potential) and a maximum of 500 workers in order to reduce the impact of a few outliers. Second, only entrepreneurial firms were retained, i.e. firms owned and controlled by private individuals with majority ownership. We dropped publicly listed firms, state-owned or state-controlled firms and those with the majority owner having less than $50 \%$ ownership. Third, only firms active in manufacturing were retained, while firms in services and retail were dropped. This was done because the questionnaire used for retail and services firms was more limited, and crucial information on technological capabilities was not asked. Finally, a few firms were excluded from the analysis because information was missing on a number of crucial variables.

This resulted in a unique firm-level dataset of 947 entrepreneurial firms with five to 500 employees,

\footnotetext{
${ }^{3}$ For more detailed information on the methodology and data collected by the World Bank Investment Climate Survey, see www.enterprisesurveys.org.
}

active in several manufacturing industries in 11 understudied SSA countries. The majority of firms are active in food processing (235 firms), followed by wood, wood products and furniture (205 firms), garments (154 firms) and metal and metal products (104 firms). Table 1 presents the composition of the sample by industry and country. It also provides a few macroeconomic indicators on population, national income per capita and performance of the manufacturing sector over time in order to illustrate the diversity that characterizes the countries under study.

\subsection{Defining HGFs in Africa}

In order to trace high-growth entrepreneurship from the sample data, a variety of approaches can be used to define HGFs in the first place. The Global Entrepreneurship Monitor (2007), for instance, which includes South Africa, advances a very simple criterion for high-growth entrepreneurs, defining them as 'established entrepreneurs who currently employ 20 or more employees' (Autio 2007, p. 8), irrespective of how many years it took to reach this size. The idea behind this mere size criterion is that many firms never reach the size of 20 employees, and those that do, can be considered 'high growth'.

Most approaches, however, develop a definition of HGFs based on growth rates. Two broad approaches can be identified for defining HGFs. One targets a certain percentage or number of firms, defining, for example, $10 \%$ of the highest growing firms as 'high growth'; the other approach defines a level of growth above which firms can be defined as high growth, such as a $60 \%$ growth in employment over 3 years, as is done by Hoffmann and Junge (2006). For our purpose of understanding the driving forces behind high-growth entrepreneurship in several African LDCs, both approaches are appealing.

Following the second approach, HGFs are generally defined according to growth criterion in terms of employment, turnover, value added or a combination of these factors, as is done in the recent work by Acs et al. (2008) ${ }^{4}$ and Delmar et al. (2003). In order to

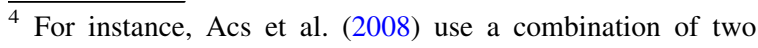
criteria: a $100 \%$ turnover growth and an employment growth qualifier - the product of absolute and relative growth-larger than two, over a 4-year period, to define 'high-impact firms'.
} 


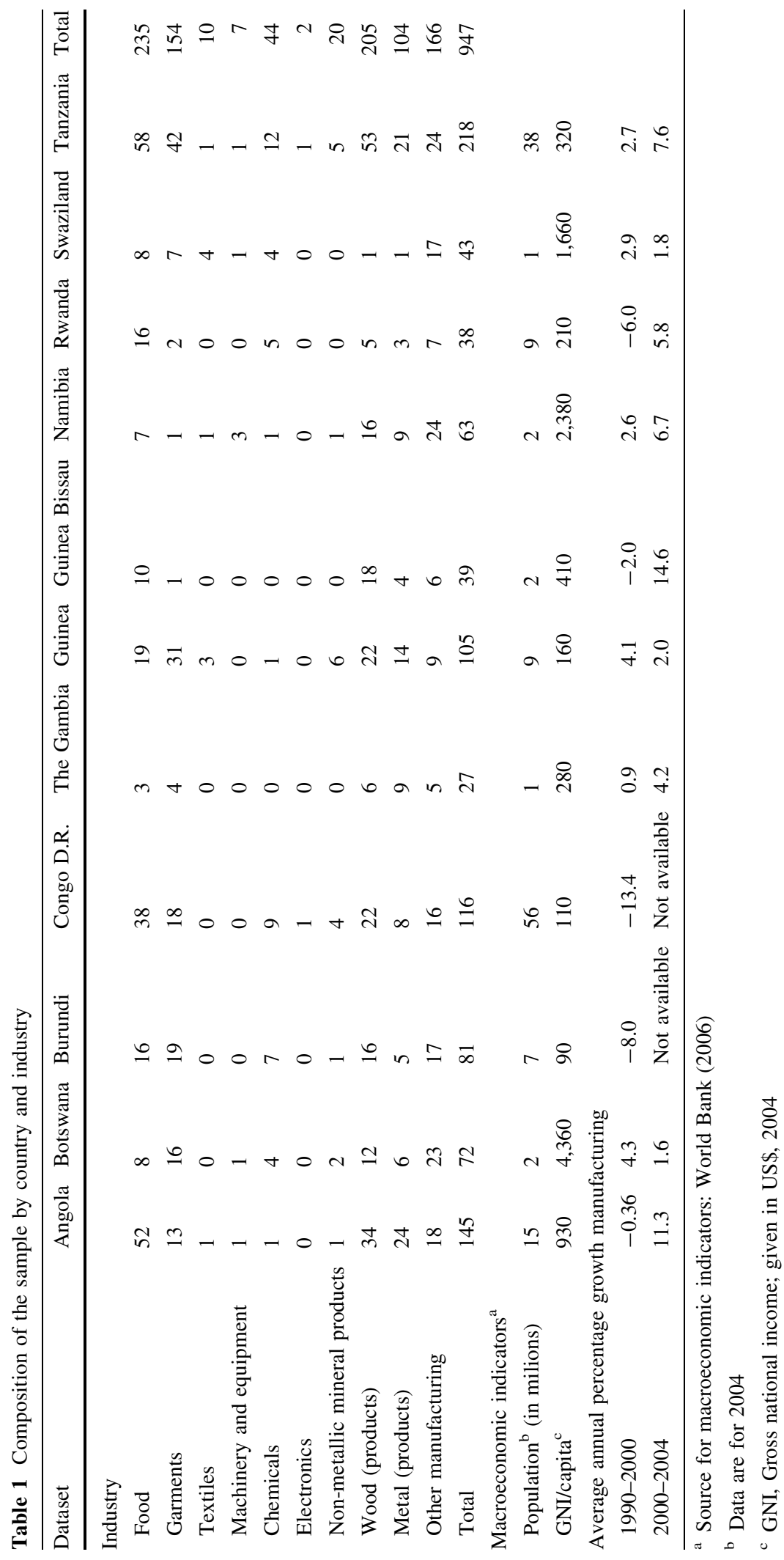


account for the effect that very small businesses have dominant growth rates, the growth rate criterion either consists of an indicator combining the absolute growth with the relative growth rate, as done in the pioneering work by Birch (1987), or it is combined with a minimum size threshold at the beginning of the growth period.

Based on this latter approach, a simple definition recently proposed by the Organization for Economic Co-operation and Development (OECD) for the development of cross-country indicators of HGFs considers as high growth firms (Eurostat-OECD 2007, p. 61):

- 'All enterprises with an average annualized growth greater than $20 \%$ per annum, over a three year period [...]. Growth can be measured by the number of employees or by turnover'.

- 'Ten employees in the beginning of the growth period' is suggested as provisional size threshold.

The choice of the threshold levels for both growth rate and initial size is, however, an arbitrary one, based on convention more than on evidence (Eurostat-OECD 2007).

From the perspective of African countries, the use of employment as the measure of growth is very appropriate and socially relevant. It also limits the problems related to turnover and value-added measures, which are expressed in monetary units and may be affected by price changes in different countries. The threshold levels of initial size and growth rate may have to be somewhat relaxed for our analysis. Due to the small size of entrepreneurial firms in many African economies, the threshold level of initial size in our study is set at more than five employees. The threshold level of the growth rate over the 3-year period 2002-2005 is set to a minimum average of $10 \%$ per annum:

High-growth firms $>10 \%$ annually, over the period 2002-2005

$>5$ employees in 2002 .

Given that high-growth businesses are typically young, an additional criterion related to the age of the firm is sometimes introduced. As such, following the guidelines of Eurostat-OECD (2007) 'gazelles' can be defined as a subset of HGFs, differentiated on the basis of age, where the age threshold is set by convention for the OECD at 5 years. In what follows, we also investigate the existence of HGFs and gazelles, as the subset of high-growth businesses started in the period 2001-2005, defined as:

$$
\begin{aligned}
\text { Gazelles } & >10 \% \text { annually, over the } \\
& \text { period } 2002-2005 \\
& 5 \text { employees in } 2002 \\
& \text { Established after } 2000 .
\end{aligned}
$$

\subsection{Differences across countries and industries}

Following the definition developed above, 205 of the 947 firms in our sample are HGFs, having increased employment by at least $30 \%$ and having started with at least five employees (see Table 2). Only one-fourth of these are young firms, 'gazelles', established after 2000. Hence, the majority of HGFs in our sample are not the newest ventures: they have a mean age of 11 years-13 years when the gazelles are not included. The HGFs seem to be well represented in food processing, the industry in which many African countries have a comparative advantage. A higher proportion of HGFs is found also in textiles and machinery and equipment, but the small number of firms in these industries does not allow us to draw any meaningful conclusions. Surprisingly, HGFs are found in small LDCs such as Rwanda, the Gambia, Guinea and Angola, and less in the richer economies of Botswana, Namibia and Swaziland.

Is the prevalence of HGFs in SSA comparable to that found in other countries? Since we do not have data on the whole population of firms, but are limited to the evidence of the sample, we cannot answer this question fully. However, some evidence can be provided by using the country comparison by Hoffmann and Junge (2006), as presented by Ahmad and Gonnard (2007), and by applying a similar definition to our sample. These authors present proportions of HGFs for 17 developed economies, using as criteria: (1) growth exceeding $60 \%$ over 3 years (over $20 \%$ growth per annum) and (2) firms with more than 15 employees. The proportion of firms in our sample that matches these criteria is shown in column 5 of Table 2. On average, $5.9 \%$ of the firms can therefore be considered to be HGFs, a figure that compares favourably to Germany, Austria, Italy, the Netherlands, Norway and Poland, each with less than $2 \%$, and is equivalent to Japan, Switzerland, UK and 
Table 2 Proportions of high-growth firms in the sample

\begin{tabular}{|c|c|c|c|c|c|c|}
\hline \multirow[t]{2}{*}{ Manufacturing sector/country } & \multicolumn{2}{|c|}{ High-growth $^{\mathrm{a}}$} & \multicolumn{2}{|l|}{ Gazelles $^{\mathrm{b}}$} & \multirow{2}{*}{$\begin{array}{l}\text { Hoffmann } \mathrm{HGF}^{\mathrm{c}} \\
\text { Percentage }\end{array}$} & \multirow{2}{*}{$\begin{array}{l}\text { Total no. } \\
\text { of firms }\end{array}$} \\
\hline & Number & Percentage & Number & Percentage & & \\
\hline Food & 61 & 25.7 & 18 & 7.6 & 7.2 & 237 \\
\hline Garments & 28 & 17.8 & 7 & 4.5 & 2.5 & 157 \\
\hline Textiles & 3 & 27.3 & 1 & 9.1 & 0.0 & 11 \\
\hline Machinery and equipment & 2 & 28.6 & 0 & 0.0 & 14.3 & 7 \\
\hline Chemicals & 7 & 15.9 & 0 & 0.0 & 6.8 & 44 \\
\hline Electronics & 0 & 0.0 & 0 & 0.0 & 0.0 & 2 \\
\hline Non-metallic mineral products & 5 & 3 & 0 & 0.0 & 5.0 & 20 \\
\hline Wood (product), furniture & 45 & 22.0 & 14 & 6.8 & 6.8 & 205 \\
\hline Metal (products) & 17 & 16.4 & 4 & 3.9 & 1.9 & 104 \\
\hline Other manufacturing & 37 & 22.2 & 7 & 4.2 & 8.4 & 167 \\
\hline Angola & 37 & 25.5 & 16 & 11.0 & 6.2 & 145 \\
\hline Botswana & 14 & 19.4 & 3 & 4.2 & 8.3 & 72 \\
\hline Burundi & 11 & 13.6 & 3 & 3.7 & 3.7 & 81 \\
\hline Congo D.R. & 19 & 16.4 & 2 & 1.7 & 2.6 & 116 \\
\hline The Gambia & 9 & 33.3 & 4 & 14.8 & 3.7 & 27 \\
\hline Guinea & 28 & 25.9 & 8 & 7.4 & 7.4 & 108 \\
\hline Guinea-Bissau & 6 & 15.4 & 1 & 2.6 & 7.7 & 39 \\
\hline Namibia & 11 & 17.5 & 1 & 1.6 & 7.9 & 63 \\
\hline Rwanda & 16 & 42.1 & 3 & 7.9 & 13.1 & 38 \\
\hline Swaziland & 9 & 20.0 & 3 & 6.7 & 2.2 & 45 \\
\hline Tanzania & 45 & 20.5 & 7 & 3.2 & 5.5 & 220 \\
\hline Total & 205 & 21.5 & 51 & 5.6 & 5.9 & 954 \\
\hline
\end{tabular}

${ }^{a}$ Definition of high-growth firms (HGFs): $>30 \%$ employment growth over 2002-2005 and >5 employees in 2002

b Definition of gazelles: HGFs established in the period 2001-2005

c Definition of HGFs following Hoffmann and Junge (2006): >60\% employment growth over 2002-2005 and >15 employees in 2002

USA, where HGFs represent 5-6\% of firms. Only Korea exceeds this value, with a $9.7 \%$ share of HGFs.

Similarly, based on a $20 \%$ yearly growth rate for 3 years and a ten-employee threshold, Petersen and Ahmad (2007) find the share of HGFs to vary between $3 \%$ and $5 \%$ in several European countries. Applying a comparable definition to our sample generates an average of $8.7 \%$ HGFs. Clearly, the high rates for Africa may be inflated by the omission of the criterion of an annual minimum growth rate of $20 \%$ (our criterion implied a minimum rate of $60 \%$ over 3 years) and the use of sample data, but there is clear evidence that high-growth entrepreneurship is observed in LDCs and that its occurrence may not differ much from that observed in the OECD countries.

\section{Empirical analysis of the determinants of HGFs}

In analysing the factors that generate HGFs, we do not limit the analysis by defining HGFs according to a strict arbitrary criterion on the required minimum level of growth. As we made clear in the previous section, using a strict criterion would have a strong a priori industry and country bias and, therefore, shows only a partial or biased view of the underlying process. ${ }^{5}$ Instead, by using quantile regression, we opted for a more flexible approach in looking for the

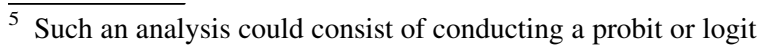
regression explaining the incidence of HGFs-defined by arbitrary criteria-by a set of determining factors, as is done in Almus (2000).
} 
factors that significantly shift growth distribution upwards and/or generate growth distributions skewed to the right, generating a higher number of HGFs, whatever criteria is applied to their definition.

\subsection{Estimation methods}

In line with earlier work, we model the growth of firms as a function of firm size and age and allow for the influence of a relevant set of factors that are related to the characteristics of the entrepreneur, the technological characteristics of the firm, and firm resources to deal with constraints originating from poor infrastructure, insecurity, transportation deficiencies and financial constraints. In addition, country-specific factors, such as those related to the macroeconomic environment, country-specific demand conditions, performance of national innovation systems or cultural differences are also expected to affect the growth perspectives of firms. The same holds for industry-wide influences that may affect firms active in the same industry across nations.

Hence, the model corresponds to the following basic specification:

$$
\begin{aligned}
& \text { Firm growth }=a_{0}+a_{1}(\text { Employment } 2002) \\
& +a_{2}(\text { Employment } 2002)^{2}+a_{3}(\text { Firm age }) \\
& +a_{4}(\text { Firm age })^{2}+a_{5}(\text { Employment } 2002) *(\text { Firm age }) \\
& +\Sigma b(\text { Entrepreneur characteristics }) \\
& +\Sigma c(\text { Technological characteristics }) \\
& +\Sigma d(\text { Resources })+\Sigma e(\text { Country dummies }) \\
& +\Sigma f(\text { Industry dummies })+\varepsilon
\end{aligned}
$$

where the dependent variable corresponds to an average annual employment growth rate over the period 2002-2005. The coefficients $a_{0}$ to $a_{5}$ are estimated, as are the coefficient vectors $b, c, d, e, f$, corresponding to a set of variables (see following section Variables) capturing the entrepreneur characteristics, technological characteristics, resources and country and industry dummies, respectively; $\varepsilon$ is the stochastic error term.

Two different estimation techniques are applied in testing the model: least squares (LS) regression and quantile regression (QR). The LS estimator measures the effects of explanatory variables at the mean firm growth, assuming a well-shaped normal distribution of growth around the mean. The LS analysis thus assumes that the explanatory variables (related to entrepreneur, firm and institutional characteristics) affect only the location of the conditional distribution of the firm's growth rates, thus leaving the scale or shape of the firm's growth distribution intact. If we represent the dependent variable firm growth by $g_{i}$ and summarize the explanatory variables, including the constant term, to a vector $X_{i}$, the LS estimator results from minimizing the sum of squared residuals, i.e., from minimizing the criterion function:

$\sum_{i=1}^{N}\left(g_{i}-X_{i} b\right)^{2} \quad(i=1, \ldots, N$ firms $)$

where $b$ is the vector of estimated coefficients. The LS analysis thus estimates the mean effects of explanatory variables $X_{i}$ on firm growth.

Quantile regression estimates the effects of the different explanatory variables at the different quantiles of the growth distribution, which are deciles in our case. Since the HGFs are located in the extreme tail of the conditional growth distributions, we are particularly interested in the factors that affect the upper deciles. Instead of minimizing the sum of squared residuals, QR coefficients result from minimizing the criterion function:

$$
\begin{aligned}
& \sum_{i=1}^{N} \rho\left|g_{i}-X_{i} b\right| I\left(g_{i} \leq X_{i} b\right) \\
& \quad+\sum_{i=1}^{N}(1-\rho)\left|g_{i}-X_{i} b\right| I\left(g_{i}>X_{i} b\right)
\end{aligned}
$$

where $\mathrm{I}(\cdot)$ is an indicator function taking the value of 1 if the condition in brackets is met and 0 otherwise, i.e., $I\left(g_{i} \leq X_{i} b\right)=1$ if $g_{i} \leq X_{i} b$ and $I\left(g_{i} \leq X_{i} b\right)=0$ if $g_{i}>X_{i} b$ (as explained in Goedhuys et al. 2008). The left term is thus a weighted sum of all negative residuals-i.e., the slower growing firms-while the right term is the weighted sum of all positive residuals-i.e., the fast growing firms.

$\rho$ is a weighting factor ranging from 0 to 1 . In the special case where $\rho=0.5$, both terms are equally weighted, and minimizing the criterion function leads to the $50 \%$ quantile. This constitutes the well-known least absolute deviation (LAD) which is less affected by outliers than other estimators, such as the LS estimator.

If $\rho=0.10$, the negative residuals in the left term have a lower weight than the positive residuals in the 
Table 3 Reported constraints to the growth of businesses

\begin{tabular}{lllll}
\hline Country & Major constraint & Constraint 2 & Constraint 3 & Constraint 4 \\
\hline Angola & Finance & Electricity & Crime & Corruption \\
Botswana & Finance & Macroeconomics & Skills & Land \\
Burundi & Electricity & Finance & Political instability & Macroeconomics \\
the Gambia & Electricity & Finance & Taxes & Land \\
Guinea Bissau & Finance & Electricity & Taxes & Political instability \\
Guinea & Electricity & Macroeconomics & Finance & Transport \\
Congo D. R. & Electricity & Finance & Macroeconomics & Political instability \\
Namibia & Finance & Corruption & Macroeconomics & Taxes \\
Rwanda & Electricity & Taxes & Finance & Transport \\
Swaziland & Informal sector practice & Crime & Corruption & Finance \\
Tanzania & Electricity & Taxes & Finance & Informal sector practice \\
\hline
\end{tabular}

right term of the expression. Minimizing the criterion function will then lead to estimated coefficients, whereby $90 \%$ of the residuals are negative-by definition, the $90 \%$ quantile or upper decile of HGFs. Low-growth firms can be examined setting $\rho=0.90$. The positive residuals in the right term have a lower weight than the negative residuals. Minimizing the criterion function will lead to estimated coefficients where $90 \%$ of the residuals are positive-i.e. the distribution is evaluated at the $10 \%$ quantile of the first decile of slow-growing firms.

\subsection{Variables}

The ICS contains a rich set of data to estimate the equation developed above.

The dependent variable is the average annual employment growth rate over the period 2002-2005, calculated as the logarithm of employment in 2005, minus the $\log$ of employment in 2002, divided by three.

Firm size is measured by employment in 2002, in logarithmic terms.

Firm age is measured in 2006, also in logarithmic terms.

The first set of dummy variables captures important characteristics of the entrepreneur. One variable for entrepreneurs of Lebanese, Indian, Middle Eastern or Asian origin is included and one for entrepreneurs of European origin, the reference being entrepreneurs of African origin. There is a dummy variable equal to one for female entrepreneurs. The influence of the educational background is captured by a dummy variable equaling one if the manager has a graduate or postgraduate degree or diploma from a tertiary college; there is one dummy variable for managers who received higher education abroad.

Variables related to technological capabilities include dummy variables for exporting firms, firms licensing technology from foreign-owned companies, firms offering formal training to the workforce and firms using a website to interact with clients and suppliers.

Product innovation is measured by a dummy variable equaling one if firms introduced any new ${ }^{6}$ or significantly improved products onto the market in the period 2002-2005. Similarly, process innovation is captured by a dummy variable for firms that introduced any new or significantly improved production processes, including methods of supplying services and ways of delivering products.

Finally, firms are confronted with growth barriers, the most constraining ones being the frequent electricity cuts and financial hardships. Entrepreneurs were asked to indicate the factors that most severely hampered the growth of the firm. These, as reported by the entrepreneurs, are presented in Table 3. Financial and electricity constraints, political instability and macroeconomic adversity, corruption, crime and transportation are among the most severe growth-hampering factors reported, which is in line with the findings given in Tybout (2000).

\footnotetext{
6 'New', defined as new-to-the-firm, largely captures the diffusion of technologies, and differs from new-to-the-market innovations that may be patentable.
} 
Table 4 Definition of variables and summary statistics

\begin{tabular}{|c|c|c|}
\hline & Definition-dependent variables ${ }^{\mathrm{a}}$ & $\begin{array}{l}\text { Mean value } \\
(\mathrm{SD})^{\mathrm{b}}\end{array}$ \\
\hline Firm growth & $\begin{array}{l}\text { Average annual employment growth over the period } 2002-2005 \text {, calculated } \\
\text { by }(\ln (\text { employment } 2005)-\ln (\text { employment } 2002)) / 2003\end{array}$ & $0.08(0.15)$ \\
\hline \multicolumn{3}{|l|}{ Entrepreneur characteristics } \\
\hline D-European & $=1$ for entrepreneurs of European origin & 0.08 \\
\hline D-Asian/Middle Eastern & $=1$ for entrepreneurs of Lebanese, Indian, Middle Eastern or Asian origin & 0.13 \\
\hline D-female & $=1$ for female entrepreneurs & 0.24 \\
\hline D-higher education & $\begin{array}{l}=1 \text { if the manager has a graduate or postgraduate degree or diploma } \\
\text { from tertiary college }\end{array}$ & 0.41 \\
\hline D-higher education abroad & $=1$ if the manager has received higher education abroad & 0.06 \\
\hline \multicolumn{3}{|l|}{ Firm characteristics } \\
\hline Firm age & Age of the firm in 2006 , in logarithmic terms & $2.34(0.64)$ \\
\hline Employment & Number of employees in 2002 , in $\log$ & $2.61(1.12)$ \\
\hline D-exporting & $=1$ if the firm exports in 2005 & 0.15 \\
\hline D-technology licensing & $=1$ if the firm uses technology licensed from a foreign-owned company & 0.09 \\
\hline D-website & $=1$ if the firm uses a website to interact with clients and suppliers & 0.12 \\
\hline D-formal training & $=1$ for a firm offering formal training to employees & 0.28 \\
\hline D-product innovation & $\begin{array}{l}=1 \text { if the firm has introduced any new or significantly improved products } \\
\text { to the market }(2002-2005)\end{array}$ & 0.57 \\
\hline D-process innovation & $\begin{array}{l}=1 \text { if the firm has introduced any new or significantly improved production processes, } \\
\text { including methods of supplying services and ways of delivering products }\end{array}$ & 0.43 \\
\hline D-own generator & $=1$ if the firm has its own generator & 0.48 \\
\hline D-own security & $=1$ if the firm invests in security (alarms, guards) & 0.58 \\
\hline D-own transportation & $=1$ if the firm uses own transport to make shipments to customers & 0.43 \\
\hline D-overdraft facility & $=1$ if the firm has an overdraft facility with a formal bank & 0.21 \\
\hline
\end{tabular}

Mean firm age and size are 13 years of age and 31 employees in 2002, respectively

a ' $=1$ ' implies the variable is a dummy variable (D) equaling one if the condition is met, otherwise the value is zero

b For dummy variables, the proportion of firms is mentioned in the last column; for continuous variables, the mean value is given, with standard deviation (SD) in parenthesis

Confronted with these obstacles, some firms may possess resources to invest in substitutes to relax the constraint. Four dummy variables are included to test whether these investments open up growth opportunities for the firms. These are: (1) whether the firm has a generator to substitute for inefficient electricity provision; (2) whether they invest in their own security to deal with crime; (3) whether they provide their own transportation facilities for shipments to customers; (4) whether they have access to flexible forms of bank credit through an overdraft facility.

Finally, the other frequently mentioned growth limitations, such as political instability, corruption and macroeconomic conditions, are country- or industry-specific, and captured by country and industry dummy variables.
Table 4 gives an overview of the definition of the variables and presents some summary statistics. The Appendix shows their correlation matrix.

\subsection{Estimation results}

The estimation results are presented in Table 5. The first column gives the results of the LS estimation-in other words, the estimation of the 'mean' effects, or more precisely the marginal effect of the explanatory variables at the mean of the growth distribution. Columns 2-10 present the results of the QR: the marginal effects at various deciles of the distribution. The reference group consists of firms in Tanzania, active in food processing, owned by male African entrepreneurs. Figure 1 shows for the reference case 


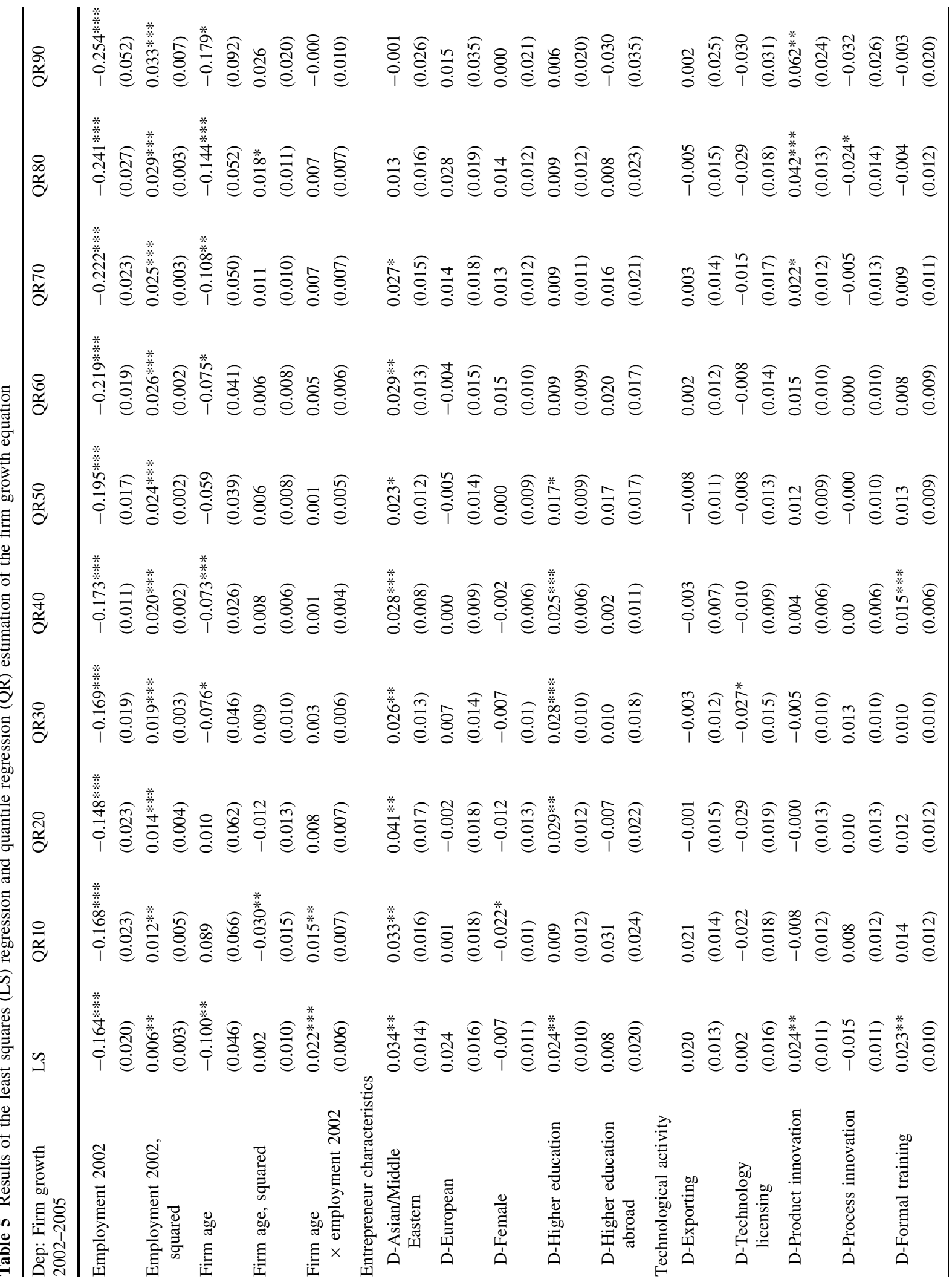




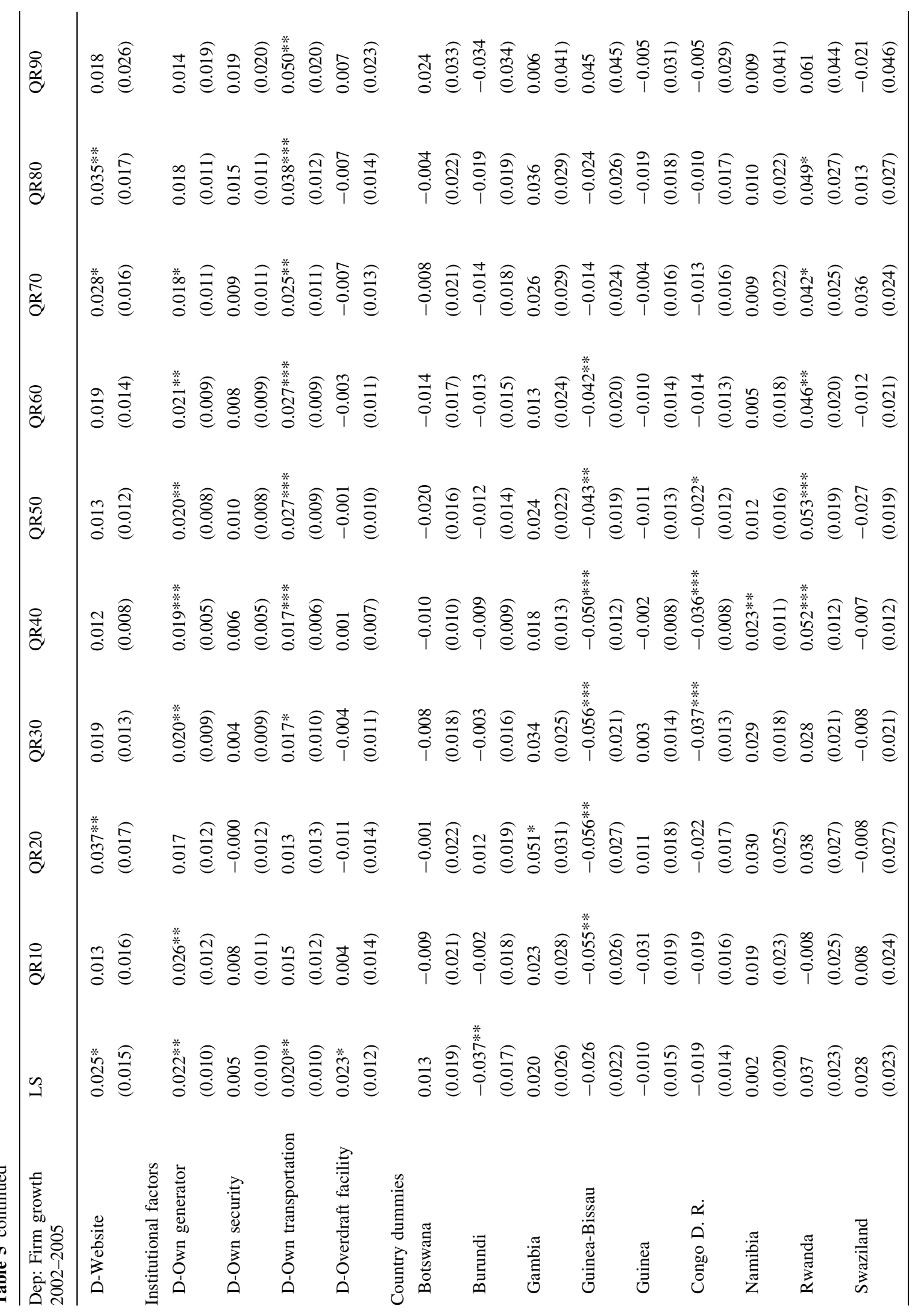




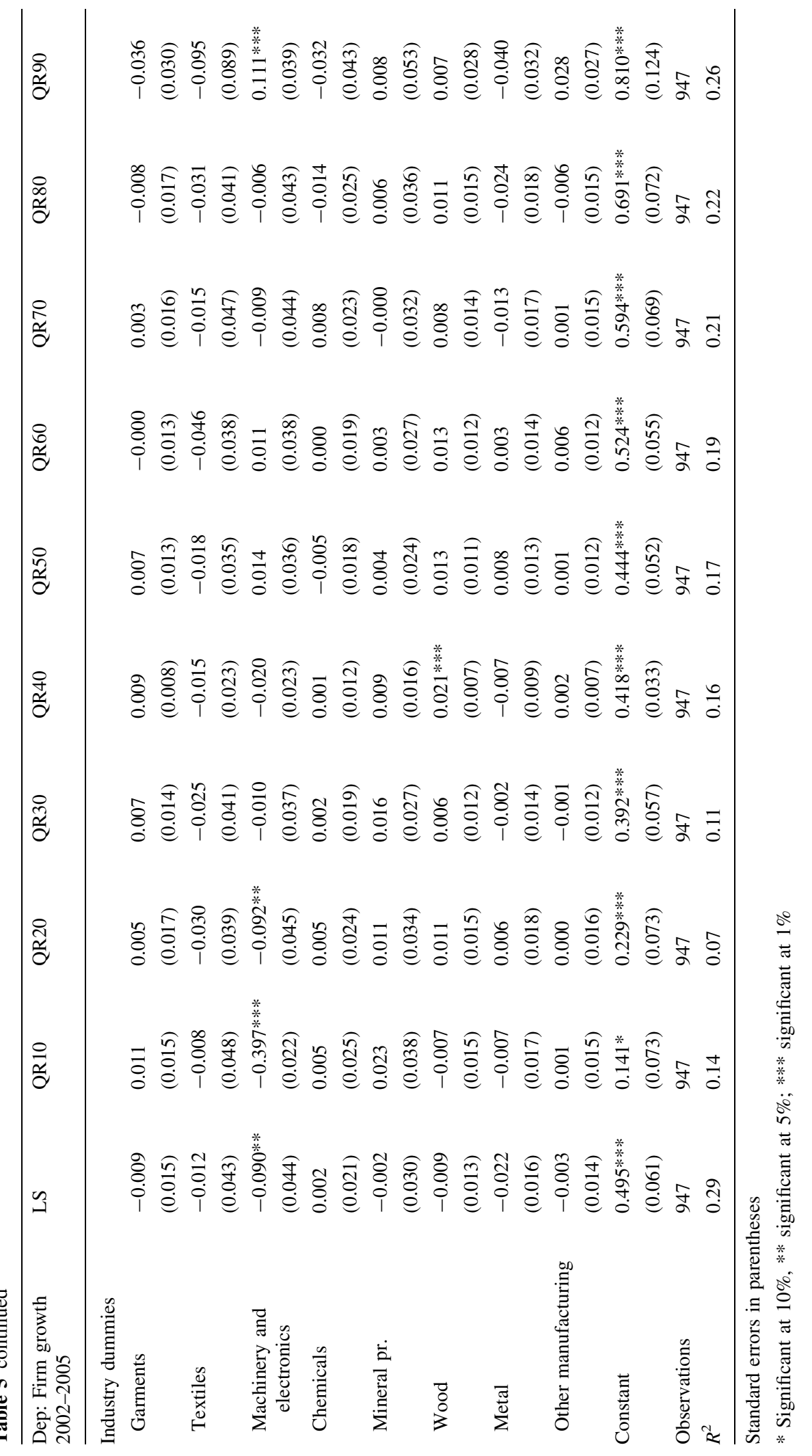




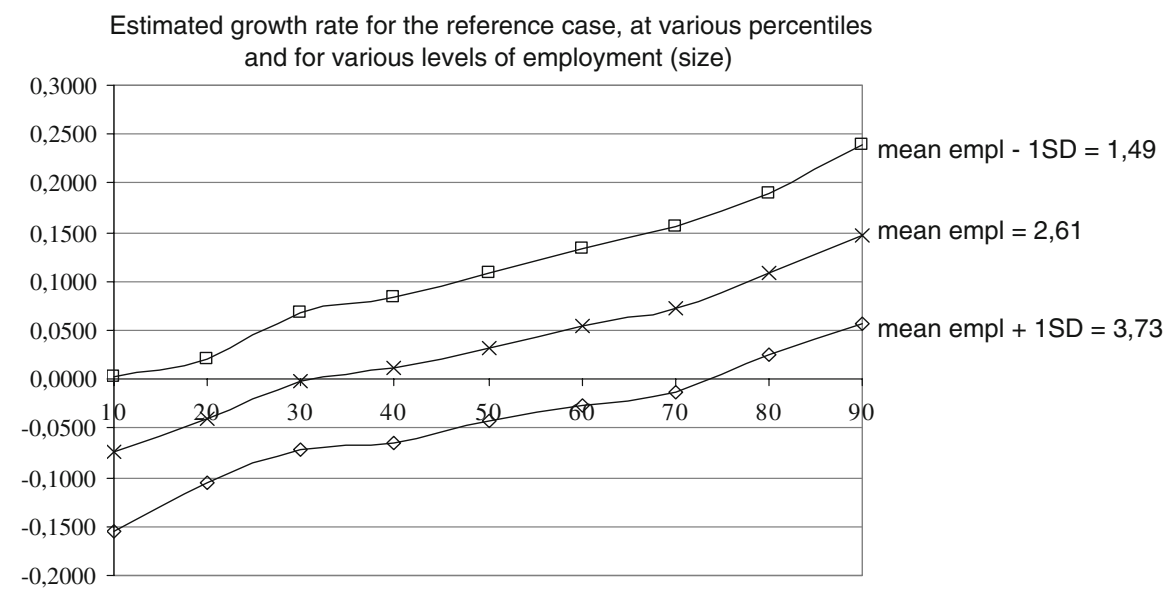

Fig. 1 Estimated growth rate for the reference case at various percentiles and for various levels of employment (size). Estimations are done at mean firm age $[\log ($ firm age $)=2.34]$ and at the mean value of employment in logarithmic terms and

and for the size and age variables valued at their sample means, the corresponding values of the deciles of the growth distribution, varying from about -0.07 to +0.15 in the upper decile.

The results of the LS estimation of the growth equation suggest that firm growth is negatively related to firm age, indicating that learning effects seem to be at work for young firms, as suggested by Jovanovic's learning models. However, while the LS estimation assumes that all firms are similarly affected, it is clear that the negative age effect is found in the upper decile, compressing the growth distribution.

The relationship between firm size and firm growth is equally negative, implying that small firms grow faster than larger ones, a finding consistent with the results from other studies on both developing and developed countries. This negative relationship has become a stylized fact in the industrial economics literature. We also find important non-linearities, as the squared size variable is positive and statistically significant. In addition to the growth rates for an average size firm, Fig. 1 shows, for the reference case, the growth rates for a larger firm size and a smaller firm size at the different quantiles. The upper curve shows the growth patterns for smaller firms (1 standard deviation smaller), while the lower curve represents those for larger firms (1 SD larger). The effect of size on growth rate does not differ too drastically over the different quantiles (the curves are at 1 standard deviation below and above the mean value, respectively. These values in logarithmic terms are 1.49, 2.61 and 3.73 and correspond to 4,13 and 42 employees, respectively

largely parallel), with a slightly more important effect in the upper decile.

Of particular interest are the effects of entrepreneur and firm characteristics on employment growth. The capabilities embodied in the entrepreneur appear to be related to the growth of the average firm. Entrepreneurs of Asian origin show employment growth levels exceeding those of African entrepreneurs by about $3 \%$ points. The effect appears to be concentrated around the median and lower tail of the distribution. This is in line with other studies on African minority entrepreneurs, which find entrepreneurs of Asian origin to exhibit superior firm performance due to the advantages of minority networks that help them to share information and resources needed for doing business. The conditional growth distribution for European entrepreneurs tends to be more skewed to the right, hosting more HGF; however, using conventional $t$ tests, the difference fails to reach significance.

In line with the literature discussed earlier, better educated entrepreneurs, with a graduate or postgraduate degree, raise the employment growth levels by $2 \%$ points versus those with a lower education. Quantile regression results suggest that the education effect impacts mainly on the lower part of the distribution, reducing the number of slowly growing firms. Training, on the other hand, has an effect concentrated around the mean and median of the distribution. No statistical differences are observed 
for the female entrepreneurs compared to their male competitors, except in the lowest decile. Firms of entrepreneurs who received a part of their education abroad or had licensed technology do not appear to grow differently from other enterprises.

More striking, firms that introduced new products or significantly improved products to the market grow stronger by $2 \%$ points according to the LS estimation of the model. However, it is clear from the QR that the disparity is much larger for the higher quantiles of the growth distribution where product innovation is associated with a 6\%-point rise in employment growth at the 90 percentile. Process innovation, which apparently does not affect employment growth of the mean firm according to the LS regression, influences firm growth in the upper tail of the growth distribution: at the 80 and 90 percentiles, it depresses growth rates by $2.4 \%$ points and $3.2 \%$ points, respectively. The effect of automated production process at the expense of employment could be observed here. These findings are in line with those of other studies that note a positive impact of product innovation and a negative impact (Harrison et al. 2005) or no impact (Benavente and Lauterbach 2008) of process innovation on employment growth. These authors argue that productivity increases resulting from process innovation may be compensated by ultimate price reductions in the final goods, or they may be used defensively. Others (e.g., Klepper 1996) argue that in maturing industries, when the number of producers declines, process innovation is more common among the survivors. It is clear that the measure of firm performance matters here and, as such, growth measured according to sales instead of employment might well reveal a different picture.

The effect of the transportation means is particularly interesting. The effect strongly supports the selfreinforcing economies it creates for growing firms. Firms that can expand their operations, and thus lower unit costs by doing so, will benefit from even stronger growth if they have the transport facilities to widen their markets and reach more customers. The quantile regression results show that for firms with their own transport facilities, the growth distribution shifts to the right and becomes more skewed, generating more firms with high growth rates. This also holds to a lesser extent for the availability of a website, the virtual means of bridging distances and communicating with customers and suppliers.
Electricity supported with the possession of a generator has a more equal effect on the location and shape of the distribution curve, causing mean growth to increase by about $2 \%$. For overdraft credit facilities, only an average effect is observed, following the results of the LS regression.

Finally, the estimated effects for the country dummies that control for the elements common to all firms in the same country indicate lower growth rates at the mean or at the lower quantiles in the QR for countries where political instability was mentioned as one of the top four constraining factors (compare Table 3). The industry effects point at a more stretched conditional growth distribution for the technology-intensive machinery and electronics sectors, with a lower mean in comparison to the traditional industries, suggesting a higher risk of doing business in those industries in SSA (see Table 5).

\section{Discussion}

Previous studies have examined firm growth as a systematic process within a well-defined supply demand growth framework. However, they generally overlook the wide dispersion of growth rates across firms that characterizes firm growth. In this article, we have taken a different perspective and focus on the country, industry, firm and institutional factors influencing the mean level as well as the dispersion of firm growth rates in a wide set of SSA countries. The results yield some powerful insights on the factors affecting not only the location but also skewness of the conditional growth distributions in relation to a set of firm characteristics and resources.

Firms that actively service their product marketsby successfully introducing new or significantly improved products and investing in own transportation for delivery or linking with clients through their own websites-show distributions skewed to the right. This implies that among these firms, the likelihood of a significant number of HGFs is much higher than among those lacking the resources to undertake this pro-active stance. If the aim of policymakers is to stimulate the number of HGFs, improving conditions to ease the access of firms to this infrastructure would appear to be a very effective approach. 
Similarly, our results point out that the provision of a good transportation network and availability of transportation are key elements in widening the relevant markets in which firms can grow. If low transport costs can be combined with scale economies in production, a self-reinforcing growth process may occur so that production in larger volume would reduce unit costs and render goods affordable for the more distant customers. Indeed, previous studies indicate that only a few firms in SSA countries produce on an efficient scale (Goedhuys and Sleuwaegen 2003). Bigsten and Söderbom (2006) acknowledge that the poorly developed transport infrastructure and unavailability of efficient transport are among the main reasons for the prevalence of small manufacturing firms in Africa, as it creates small pockets of demand generating small-scale localized producers. This is confirmed by Eifert et al. (2005) who show that African firms, in comparison to those in Asia, suffer from high infrastructural and related costs-costs for transport, logistics, telecom, water, electricity, land and buildings, marketing, accounting, security, and bribeswhich depress their productivity.

Interestingly, a number of firm-specific human capital variables, including higher education of the manager and training of the labour force, do not have a stretching effect but rather a compressing effect on the distribution. Education is an important growthshifting variable for the 'typical 'firm, causing a shift in the mean growth rate. This is also true for the possession of a generator that enables a firm to counter electricity cuts as well as for the flexible credit facilities for financing business operations. Hence, to stimulate the growth of firms in general, public intervention should aim at raising capabilities through an improved educational system that upgrades the skills of both the entrepreneurs and the labour force. At the same time, it is clear that electricity and financial constraints have industrywide effects; hence, policies tackling these obstacles to firm development may also shift the entire employment growth distribution of firms.

Finally, it is important to mention some of the limitations of this study. First, the period over which growth is analysed is relatively short. A follow-up on the growth performance of firms over a longer period of time is therefore desirable. If extended panel data become available, further analysis should investigate if there is persistence of growth among the HGFs. Second, by expressing growth in terms of employment, there is a bias towards labour-intensive activities, which overlooks most of the growth dynamics in value creation through the introduction of new processes-for example, by means of licensing and other technology transfer mechanisms. Unfortunately, reliable and comparable value-added data and other financial statistics are hard to collect for a wide representative set of firms in SSA countries. Case-study research presents itself as a useful complement to our study and should provide additional insights on the mechanisms of growth of African firms, including the many unobservable factors explaining the wide dispersion of growth rates found among those firms.

Acknowledgments The authors would like to thank Enrico Pennings, Harry Bowen and the participants of the UNUWIDER Workshop on Entrepreneurship and Development, 2123 August 2008 in Helsinki. In particular, we are grateful to Eddy Szirmai, Wim Naudé, José Ernesto Amorós and Alex Coad for their helpful comments and suggestions.

Open Access This article is distributed under the terms of the Creative Commons Attribution Noncommercial License which permits any noncommercial use, distribution, and reproduction in any medium, provided the original author(s) and source are credited. 


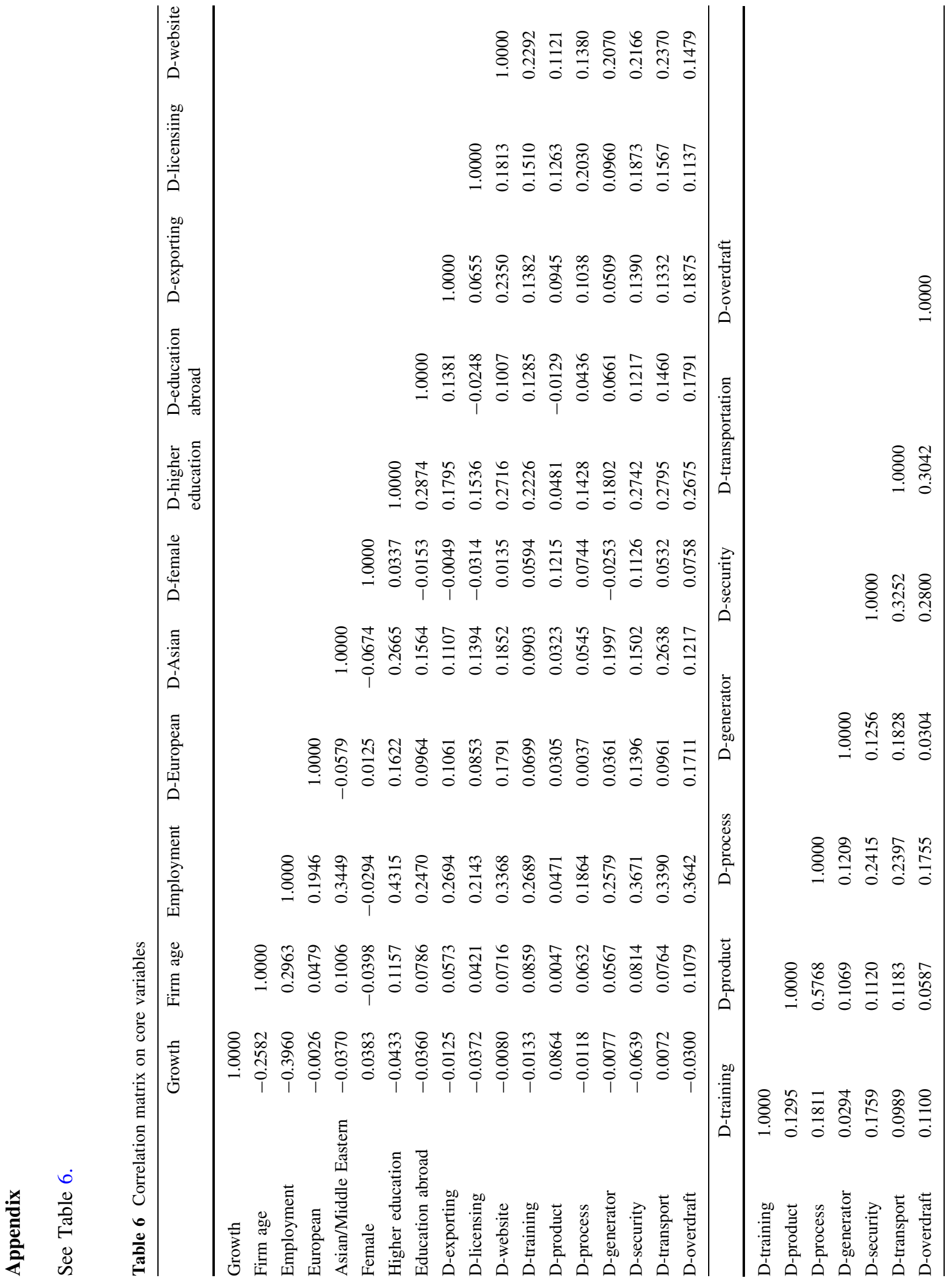




\section{References}

Acs, Z., Parsons, W., \& Tracy, S. (2008). High-impact firms: Gazelles revisited. Washington, DC: Office of Advocacy of the US Small Business Administration (SBA). www.sba.gov/advo/research/rs328tot.pdf.

Aghion, P., \& Howitt, P. (1992). A model of growth through creative destruction. Econometrica, 60(2), 323-351.

Ahmad, N., \& Gonnard, E. (2007). High-growth enterprises and gazelles. Paper prepared for the International Consortium on Entrepreneurship (ICE) meeting. Copenhagen: ICE.

Almus, M. (2000). What characterizes a fast growing firm? ZEW discussion paper 00-64. Mannheim: Centre for European Economic Research.

Audretsch, D. B. (1995). Innovation, growth and survival. International Journal of Industrial Organization, 13(4), 441-457.

Autio, E. (2007). GEM's report 2007: Global report on highgrowth entrepreneurship. London: Mazars/London Business School/Babson College. Available at: www.cspot01.babson.edu/ESHIP/research-Publications/ upload/GEM_High_Growth_Report_07b.pdf.

Benavente, J. M., \& Lauterbach, R. (2008). Technological innovation and employment: Complements or substitutes? The European Journal of Development Research, 20(2), 318-329.

Biggs, T., \& Shah, M. K. (2006). African SMEs, networks and manufacturing performance. Journal of Banking and Finance, 30(11), 3043-3066.

Biggs, T., \& Srivastava, P. (1996). Structural aspects of manufacturing in Sub-Saharan: Findings from a seven country enterprise survey. WB discussion paper 346. Washington, DC: World Bank.

Bigsten, A., \& Gebreeyesus, M. (2007). The small, the young and the productive: Determinants of manufacturing firm growth in Ethiopia. Economic Development and Cultural Change, 55, 813-840.

Bigsten, A., \& Söderbom, M. (2006). What have we learned from a decade of manufacturing enterprise surveys in Africa? World Bank Research Observer, 21(2), 241-265.

Birch, D. (1987). Job creation in America: How our smallest companies put the most people to work. New York: The Free Press.

Buchinsky, M. (1998). Recent advances in quantile regression models: A practical guideline for empirical research. Journal of Human Resources, 33, 88-125.

Calvo, J. (2006). Testing Gibrat's law for small, young and innovating firms. Small Business Economics, 26(5), 117-123.

Caves, R. (1998). Industrial organization and new findings on the turnover and mobility of firms. Journal of Economic Literature, 36(4), 1947-1982.

Coad, A. (2009). The growth of firms: A survey of theories and empirical evidence (in press). Cheltenham: Edward Elgar.

Coad, A., \& Rao, R. (2008). Innovation and firm growth in high-tech sectors: A quantile regression approach. Research Policy, 37(4), 633-648.

Delmar, F., Davidsson, P., \& Gartner, W. (2003). Arriving at the high-growth firm. Journal of Business Venturing, 18(2), 189-216.

Dunne, P., \& Hughes, A. (1994). Age, size, growth and survival: UK companies in the 1980s. The Journal of Industrial Economics, 42(2), 115-140.
Eifert, B., Gelb, A., \& Ramachandran, V. (2005). Business environment and comparative advantage in Africa: Evidence from the investment climate data. CGD working paper 56. Washington, DC: Center for Global Development.

Enos, J. (1992). The creation of technological capabilities in developing countries. London: Pinter.

Eurostat-OECD. (2007). Eurostat-OECD manual on business demography statistics. Paris: OECD.

Evans, D. E. (1987). The relationship between firm growth, size and age: Estimates for 100 manufacturing industries. Journal of Industrial Economics, 35(4), 567-581.

Fisman, R. (2003). Ethnic ties and the provision of credit: Relationship level evidence from African firms. Advances in Economic Analysis and Policy, 3(1), 1211.

Freel, M. S. (2000). Do small innovating firms outperform noninnovators? Small Business Economics, 14(3), 195-210.

Geroski, P. A. (2000). The growth of firms in theory and practice. In N. Fossu \& V. Mahnke (Eds.), Competence, governance and entrepreneurship (pp. 168-186). Oxford: Oxford University Press.

Geroski, P., \& Toker, S. (1996). The turnover of market leaders in UK manufacturing industry, 1979-86. International Journal of Industrial Organization, 14(2), 141-158.

Gibrat, R. (1931). Les Inégalités Economiques. Paris: Sirey.

Goddard, J., Wilson, J., \& Blandon, P. (2002). Panel tests of Gibrat's law for Japanese manufacturing. International Journal of Industrial Organization, 20(3), 415-433.

Goedhuys, M., \& Sleuwaegen, L. (1999). Barriers to growth of firms in developing countries, evidence from Burundi. In D. Audretsch \& R. Thurik (Eds.), Innovation, industry evolution and employment (pp. 297-314). Cambridge: Cambridge University Press.

Goedhuys, M., \& Sleuwaegen, L. (2000). Entrepreneurship and growth of entrepreneurial firms in Côte d'Ivoire. The Journal of Development Studies, 36(3), 123-145.

Goedhuys, M., \& Sleuwaegen, L. (2003). Technical efficiency, market share and profitability of manufacturing firms in Côte d'Ivoire: A technology trap? Cambridge Journal of Economics, 27(6), 851-866.

Goedhuys, M., Janz, N., \& Mohnen, P. (2008). What drives productivity in Tanzanian manufacturing firms: Technology or business environment? The European Journal of Development Research, 20(2), 199-218.

Gort, M., \& Klepper, S. (1982). Time paths in the diffusion of product innovations. The Economic Journal, 92(367), 630-653.

Harrison, R., Jaumandreu, J., Mairesse, J., \& Peters, B. (2005). Does innovation stimulate employment? A firm-level analysis using comparable micro data on four European countries. MPRA Paper No. 1245. Munich: Munich Personal RePEc Archive. Available at: www.mpra.ub. uni-muenchen.de/1245/.

Hewitt, T., \& Wield, D. (1997). Tanzanian Networks, networks in Tanzanian industrialization. Science and Public Policy, 24(6), 395-404.

Hoffmann, A., \& Junge, M. (2006). Documenting data on highgrowth firms and entrepreneurs across 17 countries. FORA working paper. Copenhagen: FORA.

Jovanovic, B. (1982). Selection and the evolution of industry. Econometrica, 50(3), 649-670. 
Klepper, S. (1996). Entry, exit, growth, and innovation over the product life cycle. The American Economic Review, 86(3), $562-583$.

Koenker, R. (2005). Quantile regression. Cambridge: Cambridge University Press.

Koenker, R., \& Bassett, G. (1978). Regression quantiles. Econometrica, 46(1), 33-50.

Koenker, R., \& Hallock, K. (2001). Quantile regression. Journal of Economic Perspectives, 15(4), 143-156.

Kumar, M. S. (1985). Growth, acquisition activity and firm size: Evidence from the United Kingdom. Journal of Industrial Economics, 33(3), 327-338.

Lall, S. (1992). Technological capabilities and industrialization. World Development, 20(2), 165-186.

Mansfield, E. (1962). Entry, Gibrat's law, innovation and the growth of firms. The American Economic Review, 52(5), 1023-1051.

McPherson, M. A. (1996). Growth of micro and small enterprises in Southern Africa. Journal of Development Economics, 48(2), 253-277.

Mead, D. C., \& Liedholm, C. (1998). The dynamics of micro and small enterprises in developing countries. World Development, 26(1), 61-74.

Mengistae, T. (1999). Indigenous ethnicity and entrepreneurial success in Africa: Some Evidence from Ethiopia. WB policy research working paper 2534. Washington, DC: World Bank.

Naudé, W. (2007). Peace, prosperity and pro-growth entrepreneurship. UNU-WIDER discussion paper 2007/02. Helsinki: UNU-WIDER.

Penrose, E. T. (1959). The theory of the growth of the firm. Oxford: Basil Blackwell.

Petersen, D. R., \& Ahmad, N. (2007). High-growth enterprises and gazelles: Preliminary and summary sensitivity analysis. Paris: OECD. Available at: www.oecd.org/dataoecd/ 47/4/39639605.pdf.
Ramachandran, V., \& Shah, M. K. (1999). Minority entrepreneurs and firm performance in Sub-Saharan Africa. Journal of Development Studies, 36, 71-87.

Roper, S. (1997). Product innovation and small business growth: A comparison of the strategies of German, UK and Irish companies. Small Business Economics, 9(6), 523-537.

Sleuwaegen, L., \& Goedhuys, M. (2002). Growth of firms in developing countries, evidence from Côte d'Ivoire. Journal of Development Economics, 68(1), 117-135.

Tybout, J. R. (2000). Manufacturing firms in developing countries: How well do they do and why? Journal of Economic Literature, 38(1), 11-44.

UNCTAD. (1996). Fostering technological dynamism: Evolution of thought on technological development processes and competitiveness: A review of the literature. Geneva, New York: United Nations.

UNCTAD (2006). The least developed countries report 2006: Productive capacities matter. Geneva: UNCTAD. Available at: www.unctad.org/en/docs/ldc2006_en.pdf.

Van der Sluis, J., van Praag, M., \& Vijverberg, W. (2004). Entrepreneurship selection and performance: A metaanalysis of the impact of education in less developed countries. Tinbergen discussion paper TI 03-036/3. Rotterdam: Tinbergen Institute. Available at: www.ssrn.com/ abstract $=625903$.

Variyam, J. N., \& Kraybill, D. S. (1992). Empirical evidence on determinants of firm growth. Economics Letters, 38(1), 31-36.

World Bank (2006) World Bank Investment Climate Survey. Washington DC: World Bank. Available at: www. enterprisesurveys.org.

Yasuda, T. (2005). Firm growth, size, age and behavior in Japanese manufacturing. Small Business Economics, 24(1), 1-15. 